\title{
Corrigendum: Region-specific variation in the properties of skeletal adipocytes reveals regulated and constitutive marrow adipose tissues
}

Erica L. Scheller, Casey R. Doucette, Brian S. Learman, William P. Cawthorn, Shaima Khandaker, Benjamin Schell, Brent Wu, Shi-Ying Ding, Miriam A. Bredella, Pouneh K. Fazeli, Basma Khoury, Karl J. Jepsen, Paul F. Pilch, Anne Klibanski, Clifford J. Rosen \& Ormond A. MacDougald

Nature Communications 6:7808 doi: 10.1038/ncomms8808 (2015); Published 6 Aug 2015; Updated 8 Dec 2016

In Figure 3 of this Article, marrow adipose tissue volumes (in panels b and c) and adipocyte numbers (in panel g) were calculated incorrectly. In Fig. 3b,c, regional MAT volumes in the 'GP to T/F J' group were normalized incorrectly to both regional marrow volume and total marrow volume instead of normalizing to total marrow volume only. As a result, the correct MAT/marrow percentages in the 'GP to T/F J' group are higher than those published. Furthermore, in Fig. $3 \mathrm{~g}$, the formula used for calculating adipocyte volumes was $\left[(4 / 3) \times \mathrm{pi} \times(\text { radius })^{2}\right]$, and this should have read $\left[(4 / 3) \times \mathrm{pi} \times(\text { radius })^{3}\right]$. As a result, the correct absolute adipocyte numbers are higher than those published. However, relative differences between all groups in this panel remain the same. None of these alterations change the original conclusions. The correct version of the figure appears below as Fig. 1. 
a
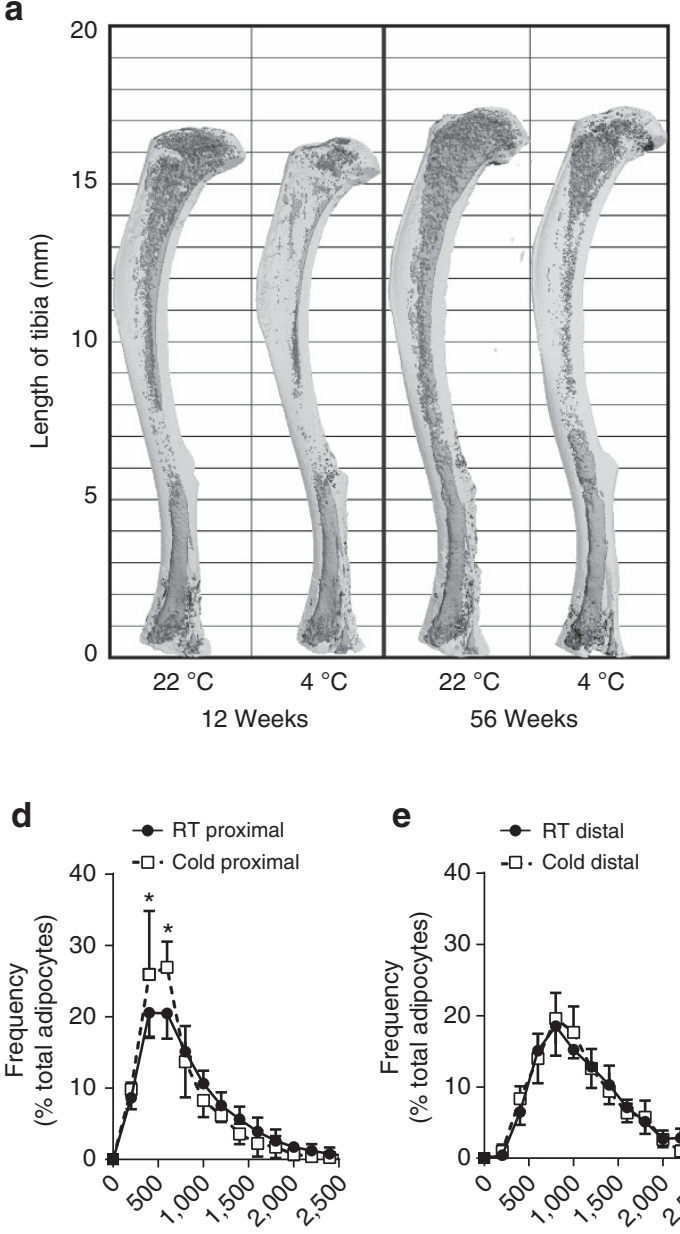

Adipocyte area $\left(\mu \mathrm{m}^{2}\right)$

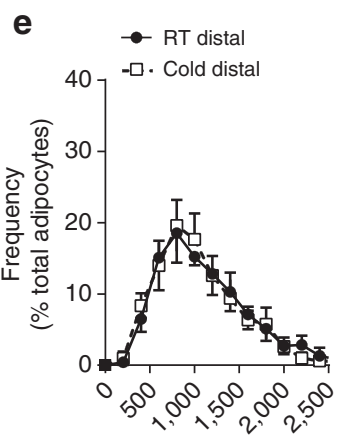

Adipocyte area $\left(\mu \mathrm{m}^{2}\right)$
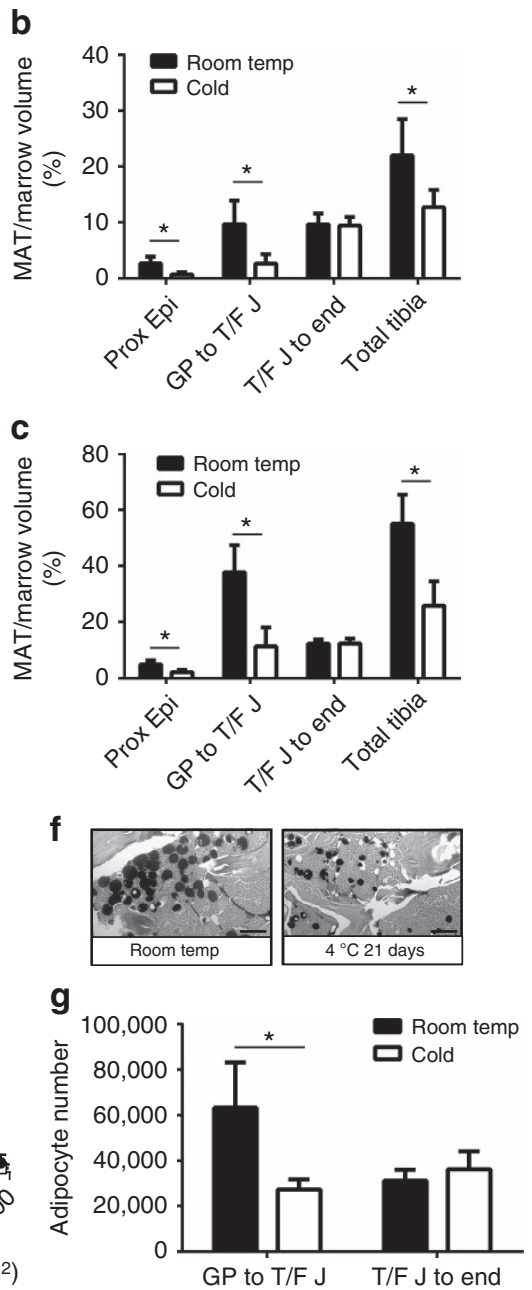

Figure 1

\footnotetext{
(c) (i) This work is licensed under a Creative Commons Attribution 4.0 International License. The images or other third party material in this article are included in the article's Creative Commons license, unless indicated otherwise in the credit line; if the material is not included under the Creative Commons license, users will need to obtain permission from the license holder to reproduce the material. To view a copy of this license, visit http://creativecommons.org/licenses/by/4.0/
}

(C) The Author(s) 2016 